The University of Maine

DigitalCommons@UMaine

Publications

Senator George J. Mitchell Center for Sustainability

Solutions

$9-2014$

\title{
The Incompatibility of Benefit-cost Analysis with Sustainability Science
}

\author{
Mark W. Anderson \\ University of Maine - Main, mark.anderson@umit.maine.edu \\ mario f. teisl \\ University of Maine - Main, teisl@maine.edu \\ Caroline L. Noblet \\ University of Maine, caroline.noblet@maine.edu \\ Sharon Klein \\ University of Maine, sharon.klein@maine.edu
}

Follow this and additional works at: https://digitalcommons.library.umaine.edu/

mitchellcenter_pubs

Part of the Economics Commons, and the Public Affairs, Public Policy and Public Administration Commons

\section{Repository Citation}

Anderson, M., Teisl, M., Noblet, C., \& Klein, S. 2014. The Incompatibility of Benefit-cost Analysis with Sustainability Science. Sustainability Science, September, 1-9. doi:10.1007/s11625-014-0266-4.

This Article is brought to you for free and open access by DigitalCommons@UMaine. It has been accepted for inclusion in Publications by an authorized administrator of DigitalCommons@UMaine. For more information, please contact um.library.technical.services@maine.edu. 
Forthcoming in Sustainability Science

The Incompatibility of Benefit-cost Analysis with Sustainability Science Mark W. Anderson (corresponding author)

Mario F. Teisl

Caroline L. Noblet

Sharon J.W. Klein

All of School of Economics

University of Maine

Winslow Hall

Orono, Maine, 04469

USA

Phone: 2075813198

Email: marka@maine.edu teisl@maine.edu

caroline.noblet@maine.edu

sharon.klein@maine.edu 
Abstract: Participants in sustainability science, as an emerging discipline, have not yet developed fully a coherent ontology, epistemology, ideology, or methodology. There is clearer agreement on the ideology of sustainability science, agreement that can be used to consider the compatibility of that ideology with methodologies brought to bear in interdisciplinary and transdisciplinary research teams. Benefit-cost analysis (BCA), one such methodology from the neoclassical economics tradition, is often used in the context of sustainability science. As currently formulated and practiced, benefit-cost analysis is incompatible with the ideology of sustainability science and should not be used to evaluate proposed solutions to sustainability problems. Other methods from economics are more appropriate for use in sustainability science.

Key words:

Benefit-cost analysis (BCA)

Philosophy of science

Ontology

Epistemology

Ideology

Methodology

Future stakeholders 
The Incompatibility of Benefit-cost Analysis with Sustainability Science

\section{Introduction}

Kates (2011) asks us to think about what kind of science sustainability science is. Before we can fully answer that question, perhaps we must first ask whether there is yet a science of sustainability. This is a legitimate question for any group of scholars who assert the need for, and promise of, an emergent discipline. In the sense of Kuhn (1970), when the dominant paradigm fails to work anymore a new paradigm is called for. The promise of a new discipline is the offer of a novel paradigm as a more effective way of knowing about phenomena of interest and putting that knowledge to work, knowledge to action. Essentially, the existing disciplinary structure is no longer an adequate framework for developing and applying new knowledge.

In this sense, sustainability science is like other emergent disciplines whose adherents are trying to plant the flag for themselves in the disciplinary landscape. But it is not enough to assert that there is a discipline called sustainability science simply because many people use the same terminology. There needs to be among those involved some coherence, if not consensus, around the ontology of the discipline (what is the understanding of the reality being studied?), its epistemology (what is accepted as knowledge about the phenomena studied?), methodology (what are valid ways of developing that knowledge?) (Gardner 2013), and ideology (what is the world view shared by those engaged in the science?) (Bromley 1990). Spash (2012) made this case about ecological economics when he said, "My contention is that our ontological 
presuppositions interact with our ideological positions to determine the epistemological approaches suitable for adoption, and in turn lead to a methodology suitable for ecological economics enquiry" (p. 44). Fuller and Loogma (2009) made a similar argument about "foresight methodology," part of the development of futures studies.

The same problems exist with sustainability science as a science; there is a ".. lack of a set of principles through which concepts and theories can be built systematically and added to an autonomous body of knowledge concerning a study object"' (SalasZapata et al. 2013 p. 607). While Bettencourt and Kaur (2011) argued that a strong network of scholars using similar terminology exists, this falls short of a convincing case for a new science, field, or discipline, all terms used by scholars referring to sustainability science. Likewise, Wiek et al. (2011) suggested what competencies are critical for graduate students in sustainability, but this also was without reference to an understanding of the underlying elements of a shared paradigm. Is it really possible to know what competencies sustainability scientists should have without knowing, or at least discussing, the elements of the paradigm?

The challenge for sustainability science is similar to that for ecological economics identified by Spash (2012). In an attempt to be inclusive, proponents of sustainability science embraced a commitment to transdiciplinarity and “...combining different ways of knowing and learning..." (Kates et al. 2001 p. 641). This is similar to what was called "methodological pluralism" in the early development of ecological economics (Norgaard 1989). Spash (2012) made a compelling case against such methodological pluralism, most fundamentally because of "...the simple impossibility of simultaneously holding two (or more) contradictory ways of understanding the meaning of knowledge" (p. 40). 
In its current state sustainability science is fraught with such contradictions. These contradictions pose practical problems for the conduct of research in sustainability science. "In non-paradigmatic fields...scholars must work out common definitions of problems and of method of approach before they can begin to work together" (Biglan 1973 p. 210).

\section{Objectives}

In this paper, our goal is not to answer fully what are or should be the underlying ontology, epistemology, and ideology of sustainability science. That will be essential work for sustainability scientists if the discipline is to persist and make meaningful contributions to human knowledge and action in the long term. One article will not accomplish such needed work. Rather, we respond in a focused way to the admonition of Ziegler and Ott (2011) that, "Sustainability science must continuously reflect on its practice and its key features if dogmatism is to be avoided" (p. 31).

We have two objectives in this paper. First, we review the perspectives of sustainability scientists to identify where there is agreement on its paradigmatic elements, with particular attention to the worldview (ideology) implicit in the science. Second, we consider one economic method, benefit-cost analysis (BCA, sometimes referred to as cost-benefit analysis) that is currently being applied as part of sustainability science. We evaluate whether or not this method is consistent with the apparent elements of these foundations of sustainability science. We urge awareness of the assumptions underlying this technique and argue that use of BCA is not consistent with many of the professed tenets of the emerging sustainability science discipline. We are not arguing that 
Forthcoming in Sustainability Science

economics does not contribute to the development of a science of sustainability. On the contrary, economics has powerful methodologies consistent with the emerging elements of the sustainability science paradigm, and economists will be essential parts of transdisciplinary teams doing sustainability science. Rather, we question the compatibility of this one method, as currently formulated in the neo-classical tradition in economics, for use in sustainability science. We see this as part of "...wide discussion within the scientific community...regarding key questions, appropriate methodologies, and institutional needs" called for by Kates et al. (2001, p. 642). This issue is particularly important for biophysical scientists and non-economist social scientists engaged in sustainability science because many of these researchers appear to be embracing BCA unaware of the extensive critique of this methodology in the economics literature.

\section{Elements of Sustainability Science}

It is not reasonable to expect that at sustainability science's young age there would be a fully developed understanding of its ontology, epistemology, ideology, or methodological commitments. Indeed, each of these can be contested realms in mature disciplines, particularly in the so-called "soft" disciplines, those which (Biglan 1973). characterized as having less paradigmatic consensus. Nevertheless, discussion of these elements is a necessary part of the maturation of the science if it is to fulfill its potential. This discussion will help us respond to Kates (2011) and learn what kind of science sustainability science is to become. The sustainability science commitment to transdisciplinarity requires that participants come to understand the fundamental assumptions of scientists from other disciplines with whom they must work. Not all 
methodologies from all disciplines are going to be part of a coherent new disciplinary framework.

There is little discussion in the sustainability science literature on its ontology. Given the prevalence of commitment to interdisciplinarity (Jerneck et al. 2011) or transdisciplinarity (Bettencourt and Kaur 2011) there is an implication that practitioners (sustainability scientists?) bring the ontological assumptions of their original discipline with them. Given the extent to which biophysical scientists, social scientists, and humanists work together in interdisciplinary or transdisciplinary teams, the likelihood is that different ontologies will underlie their work, perhaps inhibiting effective collaboration (Gardner 2013).

There is more discussion in the sustainability science literature over epistemology. Sustainability science is described inter alia as “...combining different ways of knowing and learning...” (Kates 2001 p. 641), “...an attempt to bridge the natural and social sciences..." (Jerneck et al. 2011 p. 69), "integrated research" (Kates 2011 p. 19449), and a post-normal science (Ziegler and Ott 2011), where “...the sources of intelligence are extended to include non-scientific knowledge" (Spangenberg 2011 p. 277). This reflects the very pluralism that Spash (2012) found so troubling in ecological economics. The extent to which there are contradictions between the epistemologies of various disciplines at work here may inhibit the progress of sustainability science toward offering effective solutions to society's sustainability challenges (Gardner 2013).

Alternatively, the recognition of conflict may present an opportunity to reflect upon and resolve differences. 
There is much more coherence in what is the subject of study in sustainability science and in assertions of how it is different from established disciplines. That is, there is an emerging world view of sustainability science, broad consensus that it is about interactions between nature and human, also known as coupled human/natural systems (Kates et al. 2001; Kates 2012), spans the range of spatial and temporal scales (Gibson, Ostrom, and Ahn 2000), has an orientation to the future (Padilla 2002; Jerneck et al. 2011), is use-inspired and thus intended to produce knowledge for action (van Kerkof and Lebel 2006), entails engagement with stakeholders (Cash et al. 2003), and addresses issues that are often wicked problems (Jerneck et al. 2011). It is asserted to be different from other sciences by having an inherently normative component in its ethic of producing knowledge for action (Lieserowitz, Kates, and Parris 2006; Miller 2013).

In the normative commitment inherent to these assertions, sustainability science traces its roots back at least to the Brundtland report, and practitioners will often invoke that report's definition of sustainable development as, “...development that meets the needs of the present without compromising the ability of future generations to meet their own needs" (WCED, 1987). As an expression of the worldview (ideology) at the core of the normative nature of sustainability science, this expresses concern for two groups in particular: those whose needs are not currently met and those who will inhabit the future. Miller (2013) calls this vision “...universalist (or thin) sustainability...” (p. 283). Sustainable development and thus sustainability science have an inherent normative concern for the distribution of resources in society, both intragenerationally and intergenerationally (Padilla 2002; Howarth 2007; Anderson 2013). In addition to this concept of cross-generational distribution, Hugé et al. (2011) argued that there are four 
other core principles upon which scholars and government organizations apparently agree regarding sustainable development: global responsibility ("international cooperation in a spirit of shared but differentiated responsibility"); integration of ecological, social and economic impacts and their interactions; precaution in the face of uncertainty; and participation of all concerned stakeholders in the decision-making process. (p. 6244) The normative, distributional aspect of the sustainability science ideology, along with these shared principles, brings into question the compatibility of BCA with this ideology.

\section{BCA and Its Critics}

BCA is a methodology from neoclassical welfare economics designed to apply rational choice theory to difficult policy choices in the public sector (Just, Hueth, and Schmitz 1982). It is clearly based on the fundamental ideology of the neoclassical economics paradigm (Soderbaum 1999), in its essence a commitment to the ideology of efficiency (Bromley 1990). Proponents argue that it is particularly useful when the public is confronted by decisions entailing heterogeneous costs and benefits spread across space and time, an interest shared by BCA and sustainability science. The claim for BCA is that it is a valid means of aggregating diverse types of data to determine the relative wellbeing generated by alternative choices.

In the United States, BCA has its roots in the Flood Control Act of 1933 (Bromley 1990). It was widely used in the United States in water resources development in the post-World War II era by government agencies like the Army Corps of Engineers. BCA is an explicit application of classical utilitarianism to public decision making, which is also the starting point used by neoclassical economists in discussing sustainability 
(Bromley 1998). The continued interest in BCA today can be seen in the U.S.

Environmental Protection Agency's (undated) assertion that it is one methodology it uses to "contribute to sustainability."

Simply, BCA entails the enumeration of various benefits and costs in monetary terms for a given time period, typically a year. These monetary values are derived from market data when those are available, such market data representing the revealed preferences of individuals. Since there are many benefits and costs of public projects that are not easily measured through market data, much innovation in the 1980s and 1990s went into indirect valuation techniques (Atkinson and Mourato 2008; Turner et al. 2003). These techniques included two forms of revealed preference measurement, indirect use of market data -- travel cost modeling and hedonic studies. When no market data are available either directly or indirectly, dollar values for BCA are estimated using stated preference techniques such as contingent valuation. There is no broad consensus among resource economists over the equivalence of stated and reveal preferences as measure of value or even the appropriate way to formulate the value metric (see, for example, Knetsch 2005; Knetsch 2007; Sugden 2005). Yet the use of BCA in sustainability science usually ignores these controversies in economics.

The practice of measuring values for BCA often fails even to follow the accepted theory in economics about what measures are most appropriate. Knetsch (2005) points out one example of this in the failure to reflect behavioral economics studies that show how the endowment effect yields different measures of value for the same policy. Since people clearly place larger values on losing an environmental good they currently have than on acquiring that same good when they do not yet enjoy it, the appropriate measure 
of values in BCA needs to reflect such fundamental differences, yet rarely does in practice.

Once monetary measures of benefits and costs are available for each relevant time period for the project in question (perhaps over 50+ years for water development projects like dams or aqueducts), the net benefits (i.e., benefits minus costs) are calculated for each year. Before the net benefits for each year are aggregated to determine the net benefits of the project across its full temporal scale, the net benefit values for future years are discounted. Discounting, one of the most controversial elements of BCA, is premised on the assertion that humans routinely show a preference for the present over the future; otherwise there would not be interest payments in the borrowing and lending of money. The result is the calculation of the present value of net benefits: the sum of future benefits and costs discounted into present terms using some discount rate (Just et al. 1982 p. 297). Two or more projects are easily compared after BCA is completed for each project; the one with the largest net present value is considered to contribute the most to human welfare. However, the process of discounting future benefits and costs to present values provides an implicit advantage to the present generation compared to future generations.

Given the appeal of BCA in allowing an aggregated assessment of complex public projects, it has been widely adopted (Atkinson and Mourato 2008) and its underlying logic is applied to more and more issues, including sustainability. In fact, the U.S. Office of Management and Budget (2003) requires BCA as a "key element to good regulatory analysis", and the U. S. Environmental Protection Agency recognizes BCA as instrumental in decision-making related to sustainability within the EPA and other federal agencies (U.S. EPA undated). 
With a growing recognition that there are multiple values that underlie benefits and costs of public policy choices (Anderson and Teisl 2012; Davidson 2013), there has been an expansion of the use of the non-market valuation techniques developed for BCA (Atkinson and Maourato 2008). In particular, biophysical scientists have pointed out that ecosystems provide services to humans that may be compromised by development. Past decades saw a rapid expansion of interest in ecosystem valuation (Daily 1977; Turner et al. 2003; Costanza et al. 2014), putting dollar values on: provision of flood control by wetlands, wildlife habitat by coast protection, climate stabilization or water purification by forests, protection from UV radiation damage by ozone in the stratosphere, and much more (Turner et al. 2003). These values are intended to characterize more fully in BCA the costs to humans from the development or disruption of natural systems or the benefits to humans from their protection.

One obvious problem in using BCA for measuring changes in the welfare of society is the likelihood that a given project or policy will impose costs on some individuals and generate benefit for others, it will have distributional effects. Neoclassical welfare economists assert that as long as the gainers compensate the losers for their losses and still experience a net gain, then society is better off. This result is referred to as a Pareto improvement. Since such compensation is rarely if ever made, there is a related concept called potential Pareto improvement determined by applying a decision rule termed the Kaldor-Hicks test (Farrow 1999; Persky 2001). In this approach economists who apply BCA to social policy argue that we should judge there to be an improvement in social welfare as long as the winners could have compensated the losers and have the winners still better off, even if that compensation is not made. 
The Kaldor-Hicks rule was developed in the 1930 to make welfare economics more "objective" by removing the need to make interpersonal utility comparisons in evaluating alternative states of society (Gowdy 2004). The practice of BCA almost always follows the Kaldor-Hicks rule without explicit reference to it. When discussed by neoclassical economists, the potential distributional aspects of the Kaldor-Hicks rule are justified by suggesting that economics" "comparative advantage" is in efficiency rather than distributional equity (Stavins et al. 2003). For these economists, evaluating distributional effects is left to other disciplines presumably better suited to do such work. The idea that economics has a limited purview extends to types of values to be included also, as Turner et al. (2003) argue that “...the boundaries of the non-use value category are not clear cut and some human motivations... are arguably outside the scope of conventional economic thought" (p. 494). We question limiting economic contributions to social policy in this way, though such limits are inherent to BCA.

Our goal in this paper is not to undertake a comprehensive review of the controversies within economics over BCA. That has been done well elsewhere (see, for example, Ackerman and Heinzerling 2002), and sustainability economists are working to develop improved tools for matching economists knowledge with sustainable science needs (see, for example Anderson et al. 2012). Rather, our intent here is to introduce to sustainability scientists who are not economists the issues in BCA that we believe make it incompatible with the emerging discipline. It clearly conflicts with the ideology or world view at the heart of sustainability science and therefore does not produce knowledge compatible with a coherent epistemology for sustainability science. 
We limit our focus to four controversies around BCA theory and practice relevant to sustainability science: 1) the equity implications of using values solely from stated and revealed preference methods since those values are based on the current distributions of income and wealth; 2) the assumption that future interests can be captured fairly based on the valuations of current humans that are then discounted through the net present value calculation; 3) the belief that all relevant benefits and costs are measurable in monetary units and comparable in terms of individual preferences; and 4) the fairness of aggregating benefits and costs and applying the Kaldor-Hicks rule to determine preferred policy alternatives.

\section{Roots of Incompatibility}

1) First, BCA uses stated and revealed preferences, expressed in monetary terms, to arrive at presumably comparable values for benefits and costs. In the rational actor model of welfare economics these preferences are assumed to be exogenous, not subject to the social context of the individual, and stable. "It is assumed that these preferences are stable, context independent, and internally consistent." (Gowdy 2007 p. 654.) Increasingly, economists recognize that in the real world preferences reflect the diversity of values of individuals and change in response to context and experience (Norton et al. 1998; Sugden 2005). When preferences from market data and non-market valuation studies are used in BCA, the assumption is that these data adequately reflect the valuations of the relevant set of stakeholders whose needs are to be sustained in the stated ideology of sustainability science. All of these assumptions are belied by recent 
behavioral research, and fail in this concern for stakeholders in at least two ways, raising questions of both intra- and intergenerational equity.

First, the needs of the least well off in the present are ill-served because the data are weighted to reflect more heavily the preferences of those with higher incomes and greater wealth. Both market and non-market valuation studies take the current distribution of income as a given because of the reluctance in neoclassical economics to make interpersonal utility comparisons (Gowdy 2004). Marginal utility of income is assumed to be unchanging for the individual and incomparable among individuals.

Second, the needs of the future are also ill-served since the BCA formulation assumes that the values of the future are adequately reflected in the preferences of the present, preferences that reflect the current distribution of income and are assumed to not change over time. The problem is that “...economists' models, which treat preferences as exogenous, cannot be expected to correctly characterize or guide decisions that have potential impacts over decades, centuries, and longer" (Norton et al. 1998 p. 195). The ideology of sustainability science demands that we base our methodologies on a different assumption, that “...members of future generations are morally entitled to enjoy life opportunities at least as good as those enjoyed today.” (Howarth 2007 p. 661)

Third, behavioral research shows that even individuals express different preferences depending on whether they are reflecting themselves as individuals or as citizens (Nyborg 2000). While market data and indirect measures of value designed to mimic market date may reflect some aspects of our values as individuals, certainly for public policy purposes our roles as citizens is equally important and should be reflected in how we weigh competing policies. 
The assumption of timelessness of current preferences violates the ideology of concern for the needs of the future inherent to sustainability science (Anderson 2013). This shortcoming is one that may well persist in other aspects of sustainability science practice as well, not just in BCA.

2) Second is an issue that is perhaps the greatest area of debate even among BCA proponents, that of discounting and the choice of discount rate. The basic argument for discounting is behavioral, individuals' behavior reflects preferences for current consumption over future consumption. This is revealed through interest rates in financial markets (revealed preferences) and in experimental environments (stated preferences). Traditionally the assumption in BCA has been that this preference for present over future is linear and can be captured in a fixed rate in calculating net present value indefinitely into the future.

The choice of what discount rate should be applied is contentious with arguments for market interest rate, measures of social time preference from non-market studies, or the rate of growth of capital in the macro economy (Nordhaus 2007). More recently behavioral studies led some to argue for hyperbolic discounting where the discount rate is higher in early years and then declining and plateauing at some lower rate some point in the future (Groom et al. 2005). Gowdy et al. (2013) argued that the traditional approach to discounting is flawed, partly because it “....assumes that society acts (or should act) like a single, self-regarding, optimizing, infinitely lived agent. We argue that how individuals value tradeoffs between their own present and future well-being is conceptually disjoint from the question of how social decisions about the future should be made" (p. 5102). Other scholars have suggested that the intergenerational effects of 
discounting can be addressed by differentiating between how market effects and “intangible" effects are discounted (Saez and Requena 2007).

Discounting may make sense in terms of intragenerational equity, even though behavioral economics research shows that individual "use different discount rates for different circumstances" (Gowdy 2007 p. 651). If people generally discount the future in their private behavior, is that not also appropriate in how they should view public choices that affect them directly in their life times? It is much more problematic in terms of intergenerational equity. The assumption of discounting is that the future should have less say in decision today, even when their stake is clear in such decisions. Sustainability science ideology, at least in theory, embraces the ethic of the future as stakeholders (Anderson et al. 2012). Yet discounting at any positive rate reduces or even eliminates registering their interests on current decisions. It is form of presentism embedded in BCA (Norton 2005 pp. 325-326). Mishan (1981) said of this, “...the outcome of a cost benefit analysis will depend upon...the reference point of time that is chosen. Since no purely economic condition favors one point in time over another the choice of any point of time, such as the present is arbitrary" (p. 507). Or, as Padilla (2002) argued, "The lack of consideration that discounting implies for future generations is not based on any equity criterion, but on a rather arbitrary extension of time preferences of present generations beyond their existence" (p. 70).

The application of BCA with discounting to the problem of climate change is one example of the disenfranchisement of the future inherent in this approach. Since the costs of climate change prevention and mitigation are more heavily weighted toward the present, while benefits accrue decades into the future, the effect of discounting is to make 
non-action more justified because future benefits and costs are weighted so little after discounting. While this may be consistent with the rational actor model of utilitarianism, is cannot be compatible with the ideology expressed for sustainability science. The needs of the future cannot be adequately considered in present policy if they are assumed away by discounting in BCA.

3) Third, BCA assumes that preferences of individuals, even if they were to reflect fairly those with lower incomes or those of the future, can be added together to estimate society's values of the benefits and costs of policy. The whole of value is assumed to equal the monetized sum of preferences of individuals. This assumption is an example of methodological individualism (Norton et al. 1998 p. 205; Sen 2009 p. 244246) and ignores growing evidence that there are values in sustainability not captured in individual preferences alone (Atkinson and Mourato 2012; Anderson and Teisl 2012). For example, Norton (2005 p. 335 ff.) demonstrated the importance of communal values in shaping sustainability, values not likely to be captured in BCA. He rejected “...the notion of individual preferences as a universal descriptive term to characterize and eventually to measure the social values derived from protecting environmental quality..." which is at the heart of economic thinking in BCA (Norton 1994 p. 313).

Sen (2009) made a similar point. "The utilitarian tradition works toward beating every valuable thing down to some kind of an allegedly homogenous magnitude of utility... We cannot reduce all things we have reason to value into one homogeneous magnitude" (p. 239). He termed this failure, "welfarism". Sen echoed Hubacek and Mauerhofer (2008) when they said, "The aggregation of different types of values into one 
'supernueraire' rather hides than reveals underlying values and thus is an obstacle rather than a tool to support deliberative stakeholder processes" (p. 415).

While preferences of individuals are valuable information for decision making, in BCA they are the only measures used to reduce complex problems to one powerful numeric term, net present value. This is one example of the phenomenon identified by Norton (2009) as a "Grand Simplification." The reality is that there are important values in sustainability that cannot be captured in such a simplification.

4) The fourth issue, the fairness of the Kaldor-Hicks rule, has its roots in the foundation of neoclassical economics in utilitarianism. Rawls (1971) called this basis classical utilitarianism, whose "...main idea is that society is rightly ordered, and therefore just, when its major institutions are arranged so as to achieve the greatest net balance of satisfaction summed over all the individuals belonging to it" (p. 22). The problem for Rawls was that this "Utilitarianism does not take seriously the distinction between individuals" (p. 27).

For sustainability science, the Kaldor-Hicks rule runs counter to both intra- and inter-generational concerns. The contention that we should consider it to be a welfare improvement as long as net benefits increase in the aggregate without worrying about the distribution of those benefit is contrary to the idea that sustainability is based on an inherently normative world view where distribution matters. Bromely (1990) said of the Pareto criterion at the heart of the Kaldor-Hicks rule that it is, “.... an analytical construct (inconsistent and incoherent at that) with no special claim to legitimacy beyond the tautological domain out of which it arises" (p. 96). It is easy to conceive of scenarios where net benefits increase because of welfare increases for the wealthiest in society 
while it stays the same or declines for others. This outcome would not be consistent with the expressed ideology of sustainability science. Despite this shortcoming in the fundamental logic of BCA, it continues to be used in sustainability science projects.

\section{Conclusions}

The economics literature is filled with a wealth of alternative approaches to BCA for judging whether society is better off, more sustainable, because of specific human actions and public choices. Some of these include BCA as part of a broader process, where BCA is used to address issues of efficiency only and other approaches are used to measure equity changes (Page 1997) or ecological issues (Page 1977; Norton and Toman 1997). Padilla (2002) suggests an even broader multi-part process that includes traditional BCA as a small part.

Others suggested fundamentally different frameworks that are not entirely or at all based on the utilitarianism at the heart of BCA. These include Sen's capability approach (Sen 2009; Ballet et al. 2013), the Fair Sharing Principle (Howarth 2007), the use of the

Safe Minimum Standard or Precautionary Principle Approach (Foster et al. 2000), multicriteria decision-making (Wang et al. 2009), and explicitly normative approaches like constructed order (Bromley 1998), and backcasting (Robinson 2003).

Most of the alternative approaches do not claim the simplicity and apparent objectivity of BCA. Nor do they have the advantage of communicating benefits and costs through the language of monetary values, which incorporates a measure of global understanding. What they all do is show that economists have much to offer to the growth of sustainability science as a robust area of inquiry. The alternatives also provide a 
cautionary tale for those outside of economics that not all the tools of economics are supportive of the ideology of sustainability science. Put another way, Soderbaum (1999) says, "We should realize the CBA (cost benefit analysis) project of 'value-neutral valuation' is not a very promising one. A specific ideology is built into CBA and...this ideology cannot claim sovereignty" (p. 169). This ideology is fundamentally different from the ideology of sustainability science and the two are incompatible. BCA may have a place in other paradigms, but we question is role in sustainability science as a standalone approach to project or policy evaluation. The linkage of BCA to sustainability in government policy reflects a similar flawed ideological commitment. As Bromley (1990) said, "Curiously, the identification of benefit-cost analysis with efficiency via potential Pareto improvements has come despite overwhelming evidence from within economic theory of the logical fallacies inherent therein" (p. 97). Sustainability science must avoid the same mistake. The underlying assumptions of BCA are inherently incompatible with the emerging ideology of sustainability science. Therefore it does not generate knowledge that should be included in a coherent epistemology for this emerging discipline.

Economists should continue the development of BCA or alternative decision tools so that the methodologies align more closely with the emerging paradigm of sustainability science. Sustainability scientists should understand more fully the underlying assumptions not only of this methodology, but also of methodologies brought to the table from other disciplines. The maturation of the sustainability science paradigm will require us to find common ground in terms of what methods develop knowledge appropriate for seeking solutions to our collective sustainability challenges. 
Forthcoming in Sustainability Science

Acknowledgements: This research was conducted as part of Maine's Sustainability

Solutions Initiative, supported by National Science Foundation award EPS-0904155 to Maine EPSCoR at the University of Maine. Our thanks go to Susan Gardner and to two anonymous reviewers for commenting on an earlier draft of this paper.

\section{References}

Ackerman F, Heinzerling L (2002) Pricing the priceless: Cost-benefit analysis of environmental protection. University of Pennsylvania Law Review 1553-1584

Anderson MW, Teisl M (2012) Values. Berkshire Encyclopedia of Sustainability: Volume 10 The Future of Sustainability 212-218.

Anderson MW, Teisl M, Noblet C (2012) Giving voice to the future in sustainability: Retrospective assessment to learn prospective stakeholder engagement. Ecological Economics 84:1-6

Anderson MW (2013) Intergenerational bargains: Negotiating our debts to the past and our obligations to the future. Futures 54: 43-52

Atkinson G, Mourato S (2008) Environmental cost-benefit analysis. Annual Review of Environment and Resources 33: 317-344

Ballet J, Bazin, D, Dubois, JL, Mahieu FR (2011) A note on sustainability economics and the capability approach. Ecological Economics 70: 1831-1834

Bettencourt LM, Kaur J (2011) Evolution and structure of sustainability science. Proceedings of the National Academy of Sciences, 108(49): 1954019545. 
Forthcoming in Sustainability Science

Biglan A (1973) Relationships between subject matter characteristics and the structure and output of university departments. Journal of Applied Psychology 57(3): 204 213

Bromley DW (1990) The ideology of efficiency: searching for a theory of policy analysis. Journal of Environmental Economics and Management 19(1): 86-107

Bromley DW (1998) Searching for sustainability: the poverty of spontaneous order. Ecological Economics 24(2): 231-240

Cash DW, Clark WC, Alcock F, Dickson NM, Eckley N, Guston DH, Mitchell R (2003). Knowledge systems for sustainable development. Proceedings of the National Academy of Sciences 100(14): 8086-8091

Costanza R, de Groot R, Sutton P, van der Ploeg S, Anderson SJ, Kubiszewski I, Turner RK (2014) Changes in the global value of ecosystem services. Global Environmental Change 26: 152-158

Daily GC (ed.) (1997) Nature's services: societal dependence on natural ecosystems, Island Press, Washington DC

Davidson MD (2013) On the relation between ecosystem services, intrinsic value, existence value and economic valuation. Ecological Economics 95: 171-177

Farrow S (1998) Environmental equity and sustainability: rejecting the Kaldor-Hicks criteria. Ecological Economics 27(2): 183-188

Foster KR, Vecchia P, Repacholi MH (2000) Science and the precautionary principle. Science 288(5468): 979-981

Fuller T, Loogma K (2009) Constructing futures: A social constructionist perspective on foresight methodology. Futures 41(2): 71-79 
Forthcoming in Sustainability Science

Gardner SK (2013) Paradigmatic differences, power, and status: a qualitative investigation of faculty in one interdisciplinary research collaboration on sustainability science. Sustainability Science 8: 1-12

Gibson CC, Ostrom E, \& Ahn TK (2000) The concept of scale and the human dimensions of global change: a survey. Ecological Economics 32(2): 217-239

Gowdy JM (2004) The revolution in welfare economics and its implications for environmental valuation and policy. Land Economics 80(2): 239-257

Gowdy JM (2007) Toward an experimental foundation for benefit-cost analysis. Ecological Economics 63(4): 649-655

Gowdy J, Rosser Jr JB, Roy L (2013) The evolution of hyperbolic discounting: Implications for truly social valuation of the future. Journal of Economic Behavior \& Organization 90: S94-S104

Groom B, Hepburn C, Koundouri P, \& Pearce D (2005). Declining discount rates: the long and the short of it. Environmental and Resource Economics 32(4): 445-493

Howarth RB (2007) Towards an operational sustainability criterion. Ecological Economics 63(4): 656-663

Hubacek K, Mauerhofer V (2008) Future generations: Economic, legal and institutional aspects. Futures 40(5): 413-423

Hugé J, Waas T, Eggermont G, Verbruggen A (2011) Impact assessment for a sustainable energy future-reflections and practical experiences. Energy Policy 39: 6243-6253

Jerneck A, Olsson L, Ness B, Anderberg S, Baier M, Clark E, Persson J (2011) Structuring sustainability science. Sustainability Science 6 (1): 69-82 
Just RE, Hueth DL, Schmitz A (1982) Applied Welfare Economics and Public, Policy, Prentice-Hall, Englewood Cliffs, NJ

Kates RW, Clark WC, Correll R, Hall JM, Jeager CC, Lowe I, McCarthy JJ, Schellnhuber J, Bolin B, Dickson NM, Faucheux S, Gallopin GC, Grubler A, Huntley B, Jeger J, Jodha N, Kasperson RE, Mabogunje A, Matson P, Mooney H, MoreeIII B,, O”Riordan T, Svedin U (2001) Sustainability Science. Science 292: $641-642$

Kates RW (2011) What kind of a science is sustainability science? Proceedings of the National Academy of Sciences 108(49): 19449-19450

Kates RW (2012) From the unity of nature to sustainability science: ideas and practice. In Weinstein MP, Turner RE (eds) Sustainability Science: The Emerging Paradigm and the Urban Environment, Springer New York. 3-19

Knetsch JL (2005) Gains, losses, and the US-EPA economic analyses guidelines: A hazardous product? Environmental and Resource Economics 32(1): 91-112

Knetsch JL (2007) Biased valuations, damage assessments, and policy choices: The choice of measure matters. Ecological Economics 63: 684-689

Kuhn TS (1970) The Structure of Scientific Revolutions, University of Chicago Press Chicago

Leiserowitz AA, Kates RW, Parris TM (2006) Sustainability values, attitudes, and behaviors: A review of multinational and global trends. Annual Review of Environment and Resources 31: 413-444

Miller TR (2013) Constructing sustainability science: emerging perspectives and research trajectories. Sustainability Science 8: 1-15 
Forthcoming in Sustainability Science

Mishan EJ (1981) Introduction to Normative Economics, Oxford University Press New York

Nordhaus WD (2007) A Review of the" Stern Review on the Economics of Climate Change". Journal of Economic Literature XLV: 686-702

Norgaard RB (1989) The case for methodological pluralism. Ecological Economics 1(1): $37-57$

Norton BG (1994) Economists' preferences and the preferences of economists. Environmental Values 3(4): 313-332

Norton B (2005) Sustainability: A Philosophy of Adaptive Ecosystem Management, University of Chicago Press Chicago

Norton B, Costanza R, Bishop RC (1998) The evolution of preferences: why sovereign preferences may not lead to sustainable policies and what to do about it. Ecological Economics 24(2): 193-211

Norton BG, Toman MA (1997) Sustainability: Ecological and economic perspectives. Land Economics 73(4): 553-568

Nyborg K (2000) Homo economicus and homo politicus: interpretation and aggregation of environmental values. Journal of Economic Behavior \& Organization 42(3): $305-322$

Padilla E (2002) Intergenerational equity and sustainability. Ecological Economics 41(1): $69-83$

Page T (1977) Conservation and economic efficiency: an approach to materials policy, Resources for the Future Washington DC 
Forthcoming in Sustainability Science

Page T (1997) On the problem of achieving efficiency and equity, intergenerationally. Land Economics 73(4): 580-596

Persky J (2001) Retrospectives: cost-benefit analysis and the classical creed. The Journal of Economic Perspectives 15(4): 199-208

Rawls J (1971) A Theory of Justice, Belknap Press of Harvard University Press Cambridge MA

Robinson J (2003) Future subjunctive: backcasting as social learning. Futures 35(8): 839856

Saez CA, Requena JC (2007) Reconciling sustainability and discounting in Cost-Benefit Analysis: A methodological proposal. Ecological Economics 60(4): 712-725

Salas-Zapata WA, Rios-Osorio LA, Trouchon-Osorio AL (2013) Typology of scientific reflections needed for sustainability science development. Sustainability Science 8: 607-612

Sen AK (2009) The Idea of Justice, Harvard University Press Cambridge MA Söderbaum P (1999) Values, ideology and politics in ecological economics. Ecological Economics 28(2): 161-170

Spangenberg JH (2011) Sustainability science: a review, an analysis and some empirical lessons. Environmental Conservation 38(3): 275-287

Spash CL (2012) New foundations for ecological economics. Ecological Economics 77: $36-47$

Stavins RN, Wagner AF, Wagner G (2003) Interpreting sustainability in economic terms: dynamic efficiency plus intergenerational equity. Economics Letters 79(3): 339343 
Forthcoming in Sustainability Science

Sugden R (2005) Coping with preference anomalies in cost-benefit analysis: a marketsimulation approach. Environmental and Resource Economics 32(1): 129-160

Turner RK, Paavola J, Cooper P, Farber S, Jessamy V, Georgiou S (2003) Valuing nature: lessons learned and future research directions. Ecological Economics 46(3): 493-510.

U.S. Environmental Protection Agency (undated) Benefit-Cost Analysis. http://www.epa.gov/sustainability/analytics/benefit-cost.htm\#how [Accessed March 18, 2014]

U.S. Office of Management and Budget (2003) Circular A-4: Regulatory Analysis. http://www.whitehouse.gov/omb/circulars a004 a-4 [Accessed March $18,2014]$

van Kerkhof L, Lebel L (2006) Linking Knowledge and Action for Sustainable Development. Annual Review of Environment and Resources 31: 445-477

Wan JJ, Jing YY, Zhang CF, Zhao JJ (2009) Review on multi-criteria decision analysis aid in sustainable energy decision-making. Renewable and Sustainable Energy Reviews 13(9): 2263-2278

Wiek A, Withycombe L, Redman CL (2011) Key competencies in sustainability: a reference framework for academic program development. Sustainability Science 6(2): 203-218

World Commission on Environment and Development (WCED) (1987) Our Common Future, Oxford University Press New York

Ziegler R, Ott K (2011) The quality of sustainability science: a philosophical perspective. Sustainability: Science, Practice \& Policy 7(1): 31-44 